\title{
Structure and magnetic properties of $\mathrm{Ni}-\mathrm{N}$ nanofilms
}

\author{
R.V.Shalayev, A.M.Prudnikov, S.V.Kutrovskaya*, \\ V.N.Varyukhin, A.I.Linnik, S.M.Arakelian \\ O.Galkin Institute for Physics\&Engineering \\ National Academy of Sciences of Ukraine, \\ 72 R.Luxembourg Str., 83114 Donetsk, Ukraine \\ "Vladimir State University, 87 Gorkogo Str., 600000 Vladimir, Russia
}

\section{Received October 5, 2013}

\begin{abstract}
All range of nanostructured films of nickel nitrides is synthesized by the method of magnetron sputtering (from the phase of $\mathrm{Ni}$ and up to the phase of $\mathrm{Ni}_{2} \mathrm{~N}$ ) and was investigated the change in the magnetic properties. We found out the globular structure of paramagnetic phases of $\mathrm{Ni}_{3} \mathrm{~N}$ and $\mathrm{Ni}_{2} \mathrm{~N}$, and also the ferromagnetic behavior of $\mathrm{Ni}_{4} \mathrm{~N}$ phase is confirmed.
\end{abstract}

Методом магнетронного распыления синтезирован весь спектр наноструктурных пленок нитрида никеля (от фазы $\mathrm{Ni}$ до фазы $\mathrm{Ni}_{2} \mathrm{~N}$ ) и исследовано изменение их магнитных свойств. Обнаружена глобулярная структура парамагнитных фаз $\mathrm{Ni}_{3} \mathrm{~N}$ и $\mathrm{Ni}_{2} \mathrm{~N}$, подтверждено ферромагнитное поведение фазы $\mathrm{Ni}_{4} \mathrm{~N}$.

Структура та магнитні властивості наноплівок Ni-N. Р.В.ШШалаєв, А.М.Прудников, С.В.Кутровсъка, В.Н.Варюхин, А.И.Линник, С.М.Аракелян.

Методом магнетронного розпилення синтезовано весь спектр наноструктурних плівок нітриду нікелю (від фази $\mathrm{Ni}$ до фази $\mathrm{Ni}_{2} \mathrm{~N}$ ) і досліджено зміну їх магнітних властивостей. Виявлено глобулярну структуру парамагнітних фаз $\mathrm{Ni}_{3} \mathrm{~N}$ i $\mathrm{Ni}_{2} \mathrm{~N}$, підтверджено феромагнітну поведінку фази $\mathrm{Ni}_{4} \mathrm{~N}$.

\section{Introduction}

In recent years, nitrides of transition metals such as $\mathrm{Fe}$, Co, Ni, attracted the interest of researchers due to its unique physical properties. These materials have a high potential for practical applications in the fields of science and technology, as semiconductor technology, magneto-optics, sensor devices and magnetic storage devices [1]. As is well known, the implantation of nitrogen into the structure of the transition metals can actively manage their properties, in particular, magnetic properties. But unfortunately nitrides of metals (such as $\mathrm{Ni}$ and (Co) often are metastable phases and not all of them are clearly identified. This pri- marily refers to the nickel and nickel nitride. Although they actively investigated for more than 70 years, there is still no confirmed data for some phases of $\mathrm{Ni}-\mathrm{N}$.

In this work, a number of nitride phases of nickel ( $\mathrm{Ni}$ solid solution with nitrogen, $\mathrm{Ni}_{4} \mathrm{~N}, \mathrm{Ni}_{3} \mathrm{~N}$ and $\mathrm{Ni}_{2} \mathrm{~N}$ ) were synthesized using magnetron sputtering of nickel target, which was confirmed by X-ray analysis, and their magnetic properties were investigated.

\section{Experimental}

Nickel and nickel nitride films prepared by magnetron sputtering of nickel target on the substrate of quartz glass and the coating glass at a temperature of $180-350^{\circ} \mathrm{C}$ in an $\mathrm{Ar}$ atmosphere, with the addition of $\mathrm{N}_{2}$ 


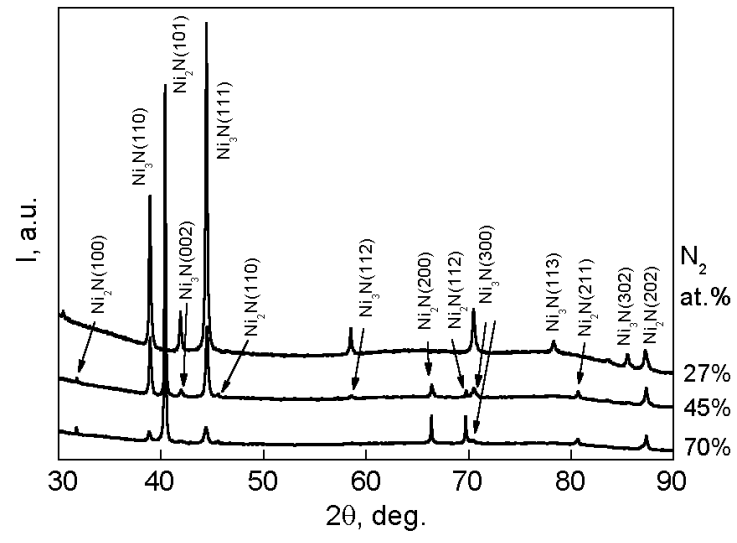

Fig. 1. XRD spectra of nickel nitride films grown under nitrogen concentrations in the growth atmosphere of above 20 vol. $\%$.

(from 2 to $100 \mathrm{rpm} . \%$ ). It was performed $\mathrm{X}$-ray diffraction analysis of the films using a diffractometer DRON-3 CoK $\alpha$-rays and Bragg-Brentano diffractometer BRUKER ADVANCE HR in $\mathrm{CuK}_{\alpha}$-radiation. The surface morphology of the films and their thickness was analyzed by field emission scanning electron microscopy (SEM) on the instrument JEOL JSM-6490 LV, as well as atomic force microscopy (AFM) probe with nano-lab Ntegra Aura. Magnetic properties of the films was investigated using inductively frequency equipment [2].

\section{Results and discussions}

X-ray analysis of the obtained specimens shows a gradual transition from the formation of pure metallic nickel (cubic phase) and a solid solution of nitrogen in nickel to the nitrides of nickel of varying stoichiometry: $\mathrm{Ni}_{4} \mathrm{~N}, \mathrm{Ni}_{3} \mathrm{~N}, \mathrm{Ni}_{2} \mathrm{~N}$ when the concentration of nitrogen gas in a growth atmosphere increases from 0 to $100 \mathrm{vol}$. \% [3] (Fig. 1). At nitrogen concentrations in the gas phase above 50 vol. \%. predominance of the $\mathrm{Ni}_{2} \mathrm{~N}$ phase observed in the film structure (Fig. 1).

From the XRD spectra can be seen [3] that the films are pure nickel phase or solid solution of nitrogen in nickel at the nitrogen concentration in the gas phase up to 2 vol. \%. Ferromagnetic phase of nickel nitride $\mathrm{Ni}_{4} \mathrm{~N}$ (FCC) stable forms at concentrations of nitrogen in the growth environment is not more than $2-4 \%$, and at further increase in the nitrogen content is replaced by the phase $\mathrm{Ni}_{3} \mathrm{~N}$ (HCP). At nitrogen concentrations in the gas phase from 6 to 27$30 \%$ only one phase $\mathrm{Ni}_{3} \mathrm{~N}$ is observed in the growing structure, which is uniquely identified by the number of reflections. With a further increase in the nitrogen concentration we seen the appearance of reflexes of a new phase (see Fig. 1), which was identified by us as $\mathrm{Ni}_{2} \mathrm{~N}$ (BCT) . This phase is extremely rare $[4,5]$, and so far little studied. The intensity of its reflexes increases with further increase of the nitrogen concentration in the growth environment and has the maximum at $100 \% \mathrm{~N}_{2}$. The film still contains a small number of $\mathrm{Ni}_{3} \mathrm{~N}$ phases, as can be seen from the corresponding $\mathrm{X}$-ray diffraction. Thus, the heterophasic system $\mathrm{Ni}_{3} \mathrm{~N}+\mathrm{Ni}_{2} \mathrm{~N}$ formed, when the nitrogen concentration in the gas phase above 30 vol. \%, with advantage the last phase when the concentration of nitrogen increase.

The HR scanning electron microscope datas show that films grown at nitrogen concentrations below 6 vol. \%. (solid solution of nitrogen in nickel and the phase $\mathrm{Ni}_{4} \mathrm{~N}$ ) consist of packed nanocolumns with
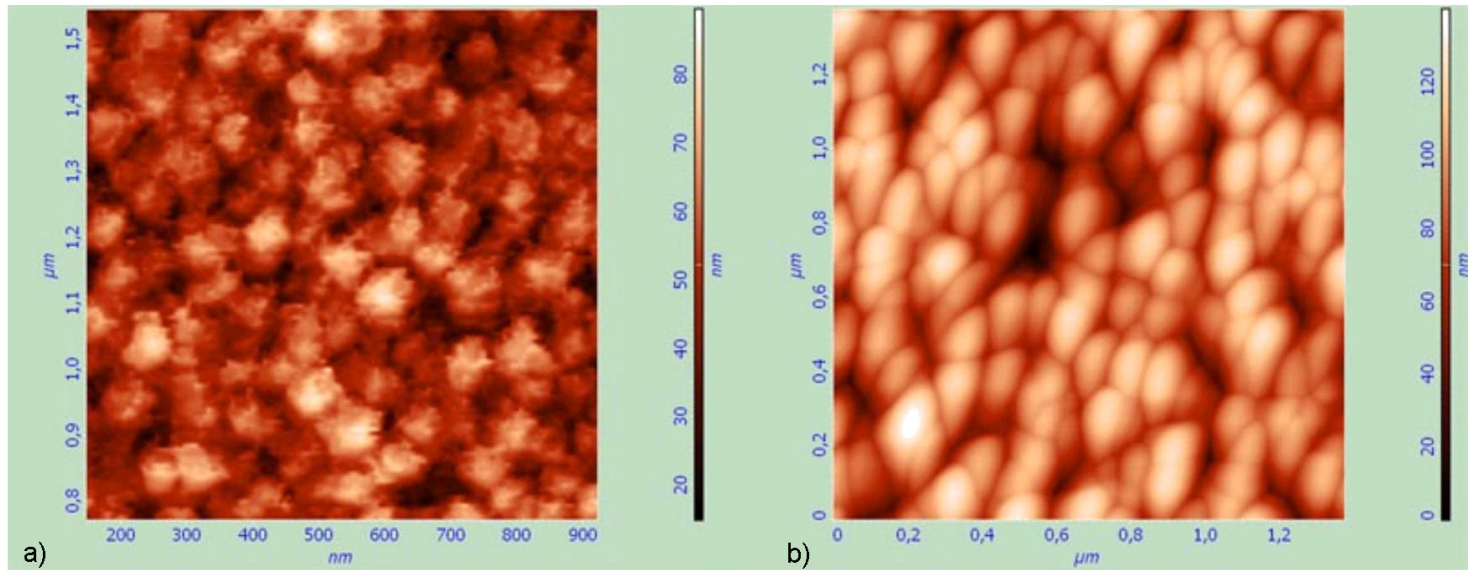

Fig. 2. AFM-images of the surface of the Ni-N films, grown in a $100 \% \operatorname{Ar}$ (a) and $100 \% \mathrm{~N}_{2}$ (b) atmosphere. 


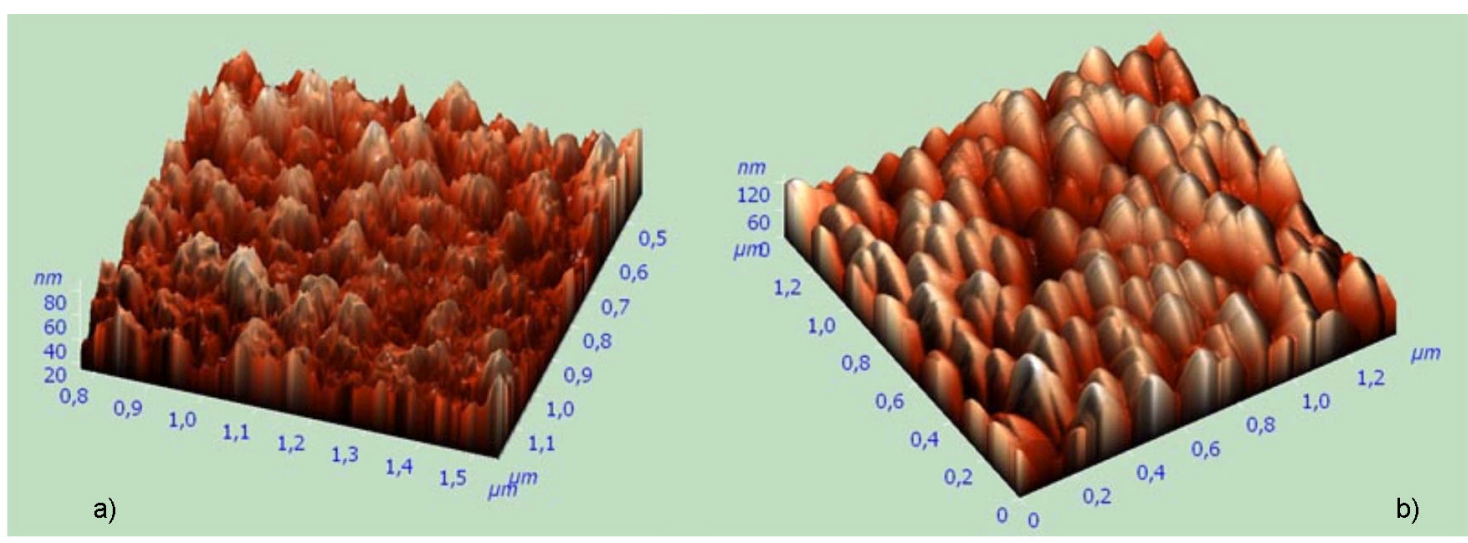

Fig. 3. AFM 3D-images of the surface of the Ni-N films, grown in a $100 \%$ Ar (a) and $100 \% \mathrm{~N}_{2}$ (b) atmosphere.

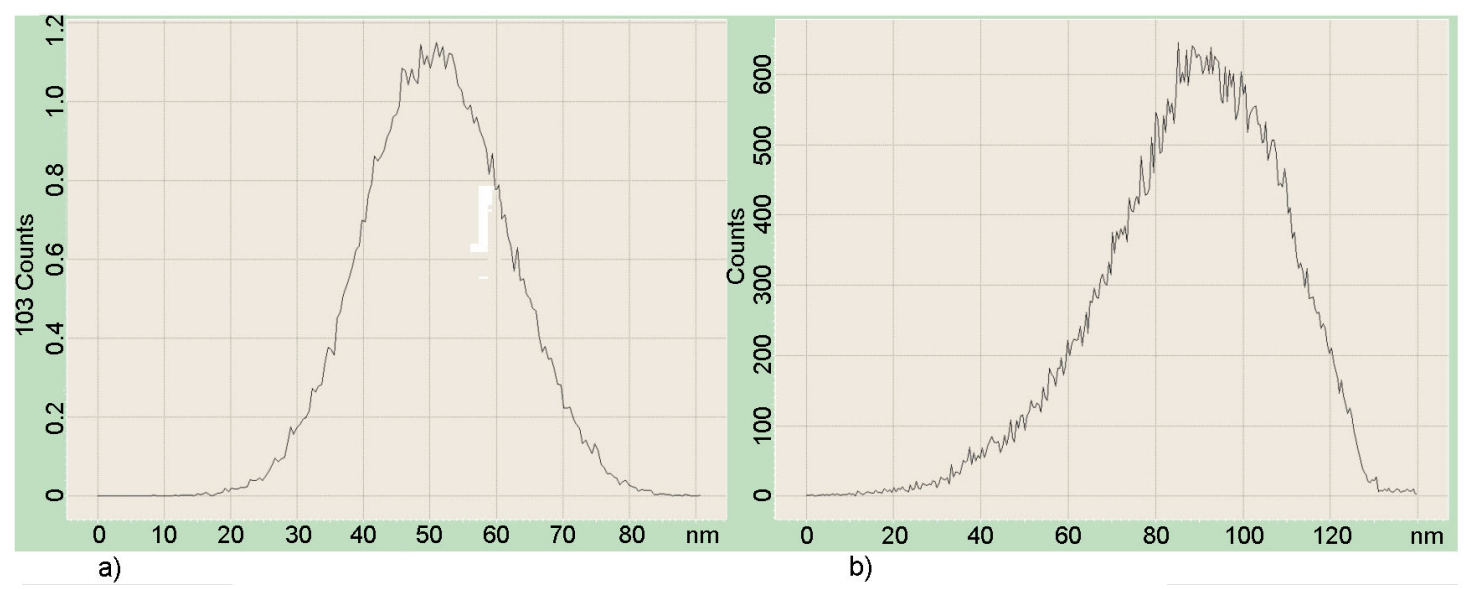

Fig. 4. A histogram of heights for AFM images of Ni-N films, grown in a $100 \% \operatorname{Ar}(a)$ and $100 \%$ $\mathrm{N}_{2}$ (b) atmosphere. The abscissa is the height in $\mathrm{nm}$ and the ordinate is a number of points whose values lie in the range of heights from $h$ to $h+h \_$step.

average diameter of $\sim 50-70 \mathrm{~nm}$ [2]. With increasing content of nitrogen in the gas phase above 8 vol. \% (films containing phase $\mathrm{Ni}_{3} \mathrm{~N}$ and $\mathrm{Ni}_{2} \mathrm{~N}$ ), there is a noticeable change in the film structure. They have a typical globular structure with an average size of elements of $\sim 20-40 \mathrm{~nm}$, and the association of individual globules into aggregates of size up to $500 \mathrm{~nm}$ observed.

AFM-microscopy also shows the structural features of these samples in Fig. 2: the columnar structure (a) of the film grown at a nitrogen concentration about $0 \%$ and globular structure (b) of the film grown at $100 \%$ nitrogen.

The complex morphology of the samples surface of nickel nitride confirmed by 3Dimages of the surface obtained by AFM. Figure 3 shows the 3D-image of the surface of the films obtained in pure Ar-atmosphere (a) and pure $\mathrm{N}_{2}$ atmosphere (b). Figure 3 (a) is a sample of pure nickel (with a small amount of dissolved nitrogen). It is clearly seen "sharp" needle-shaped structure formed by individual thin nanocolumns. Such surface is characterized by a normal (Gaussian) distribution of nanocolumns heights on the selected area with an average height about $50.9 \mathrm{~nm}$. However, $80 \%$ of sudden changes in needle formations are enclosed in a range of heights from 30 to $70 \mathrm{~nm}$ (Fig. 4a). Arithmetic average roughness (according to ISO 4287/1) for this area equals $S_{a}=8.6 \mathrm{~nm}$. In this case, the Fourier analysis of the structure revealed no short-range order of the morphology.

Heterophase film $\mathrm{Ni}_{3} \mathrm{~N}+\mathrm{Ni}_{2} \mathrm{~N}$ in Fig. 3 (b) has a more smooth surface topography, characteristic for globules. This area is characterized by an asymmetric distribution of heights (see Fig. 4 (b)): a hollow leading edge is dropped when the average height of the relief $\approx 87.4 \mathrm{~nm}$. Arithmetic average roughness (according to ISO 4287/1) for the area equals $S_{a}=16.2 \mathrm{~nm}$. This means that 
the globules base area decreases sharply with increasing their height.

The magnetic properties of the films obtained with the nitrogen content in the growth atmosphere more than 6 vol. \% (nitride phases $\mathrm{Ni}_{3} \mathrm{~N}$ and $\mathrm{Ni}_{2} \mathrm{~N}$ ) did not find them in ferromagnetism, which confirms the early findings [6].

As for the films obtained at low concentrations of nitrogen which exhibit ferromagnetism, the measurement of the saturation magnetization $4 \pi \mathrm{MS}$ [2] shows that at the nitrogen content increase in the films and the phase transition from $\mathrm{Ni}$ (solid solution of nitrogen in nickel) to the $\mathrm{Ni}_{4} \mathrm{~N}$ phase, the magnetization at room temperature is reduced from $\sim 3500 \mathrm{G}$ to $\sim 800 \mathrm{G}$. The Curie temperature of $\mathrm{Ni}_{4} \mathrm{~N}$ phase was estimated about $500 \mathrm{~K}$.

\section{Conclusions}

We have thus shown that the magnetron sputtering is an effective method for the synthesis of a variety of nanostructured nickel nitride films from phase $\mathrm{Ni}$ to $\mathrm{Ni}_{2} \mathrm{~N}$ phase (currently poorly studied). It has been found that $\mathrm{Ni}_{3} \mathrm{~N}$ and $\mathrm{Ni}_{2} \mathrm{~N}$ films are not ferromagnetic and have a globular structure, while the pure nickel films and solid solution of nitrogen in nickel with impurity of $\mathrm{Ni}_{4} \mathrm{~N}$ phase are ferromagnetic and nanocolumnar.

Work performed under the Ukr./Rus. project No.02-02-12 (U).

\section{References}

1. P.R.Cantwell, U.J.Gibson, D.A.Allwood, H.A.M.Macleod, J. Appl.Phys., 100, 093910 (2000).

2. A.I.Linnik, A.M.Prudnikov, R.V.Shalaev et al., Techn. Phys. Lett., 38, 499 (2012).

3. A.I.Linnik, A.M.Prudnikov, R.V.Shalaev et al., Techn. Phys. Lett., 39, 143 (2013).

4. H.A.Wriedt, Bull. Alloy Phase Diagrams, 6, 558 (1985).

5. G.J.W.R.Dorman, M.Sikkens, Thin Solid Films, 105, 251 (1983).

6. D.Vempaire, F.Fettar, L.Ortega et al., J.Appl. Phys., 106, 073911 (2009). 